\title{
Orthorhombic 11C pyrrhotite from Michałkowa, Góry Sowie Block, The Sudetes, Poland - preliminary report
}

\author{
Maciej Rybicki \\ Tomasz Krzykawski
}

Faculty of Earth Sciences, University of Silesia, Będzinska 60 Str., 41-200 Sosnowiec, Poland;

maciej.rybicki@us.edu.pl,

tomasz.krzykawski@us.edu.pl

\begin{abstract}
This study provides the preliminary report about first occurrence of orthorhombic $11 \mathrm{C}$ pyrrhotite $\left(\mathrm{Fe}_{(1-\mathrm{x})} \mathrm{S}\right)$ from the Sudetes, Poland. Samples of pyrrhotite-containing two-pyroxene gabbro were found in a classic pegmatite locality in Michałkowa near Walim in the Góry Sowie Block. Based on microscopic methods, pyrrhotite is associated with pentlandite, chalcopyrite, chromite, ilmenite, gersdorffite, magnetite, biotite, magnesiohornblende, clinochlore, lizardite and talc. X-Ray diffraction (XRD) indicate that pyrrhotite has orthorhombic $11 \mathrm{C}$ structure and it is characterized by: $\mathrm{a}=3.433(9) \AA, \mathrm{b}=5.99(2) \AA, \mathrm{c}=5.7432(5) \AA, \beta=90^{\circ}$ and $\mathrm{d}_{102}=$ $2.06906 \AA$. Mössbauer studies confirmed the XRD data. Pyrrhotite has three sextets with hyperfine parameter values $30.8 \mathrm{~T}$ for sextet $\mathrm{A}, 27.9 \mathrm{~T}$ and $25.8 \mathrm{~T}$ for sextets $\mathrm{B}$ and $\mathrm{C}$ respectively, indicating orthorhombic structure, the composition near $\mathrm{Fe}_{10} \mathrm{~S}_{11}$ and $\mathrm{x}=0.0909$.
\end{abstract}

Key words: orthorhombic pyrrhotite, Polish Sudetes, Góry Sowie Block

DOI: $10.2478 / \mathrm{ctg}-2014-0022$

Received: $3^{\text {rd }}$ August, 2014

Accepted: $5^{\text {th }}$ September, 2014

\section{Introduction}

Pyrrhotite is one of the most common sulfide minerals, widespread in many rocks and is an important component of the sulfide ore deposits, especially in those that contain $\mathrm{Ni}$, $\mathrm{Cu}$ and $\mathrm{Pt}$ group elements (De Villiers and Liles 2010). The pyrrhotite group is nonstoichiometric and has the general formula of $\mathrm{Fe}_{(1-\mathrm{x})} \mathrm{S}$ where $0 \leq \mathrm{x}<0.125$ and is based on the hexagonal close-packed NiAs structure (Becker et al. 2011). The nonstoichiometry of pyrrhotite is caused by a deficiency of iron atoms in the Fe-layers (Kontny et al. 2000). Numerous pyrrhotite superstructures have been described in the literature, but only three of them are naturally occurring at ambient conditions (e.g. Pósfai et al. 2000; Fleet 2006; Becker et al. 2011). This includes the stoichiometric hexagonal FeS known as troilite
(Evans 1970), the ferrimagnetic 4C pyrrhotite with an ideal composition $\mathrm{Fe}_{7} \mathrm{~S}_{8}$ and monoclinic crystallography (Powell et al. 2004) and non-magnetic orthorhombic or monoclinic pyrrhotite formally described as $\mathrm{NC}$ pyrrhotite where $\mathrm{N}$ represents the number of repetitions of the NiAs unit cell along the caxis (Carpenter and Desborough 1964; Morimoto et al. 1970; Koto et al. 1975; Pósfai et al. 2000; De Villiers and Liles 2010; Becker et al. 2011; Liles and De Villiers 2012). The non-magnetic NC pyrrhotites have a range of compositions varying from $\mathrm{Fe}_{9} \mathrm{~S}_{10}$ to $\mathrm{Fe}_{11} \mathrm{~S}_{12}$ including three stoichiometric polytypes: $5 \mathrm{C}$ pyrrhotite with $\mathrm{Fe}_{9} \mathrm{~S}_{10}$ formula (De Villiers et al. 2009), 11C polytype (Yamamoto and Nakazawa 1982) and 6C pyrrhotite (Koto et al. 1975) with $\mathrm{Fe}_{10} \mathrm{~S}_{11}$ and $\mathrm{Fe}_{11} \mathrm{~S}_{12}$ formulas respectively. 
This study provides the preliminary report about the orthorhombic 11C pyrrhotite from the Polish Sudetes. Samples of two-pyroxenes gabbro were found in a classic pegmatite locality near Walim in the Góry Sowie Block (Fig. 1), on the right bank of the Młynowka River in Michałkowa (Michelsdorf), better known as the sarcopside type locality (Websky 1868), where feldspars were exploited before the World War II in open pits and adits (Lodziński and Sitarz 2009). These rocks are commonly occurring as a veins in the Sowie Mts. gneissic block.
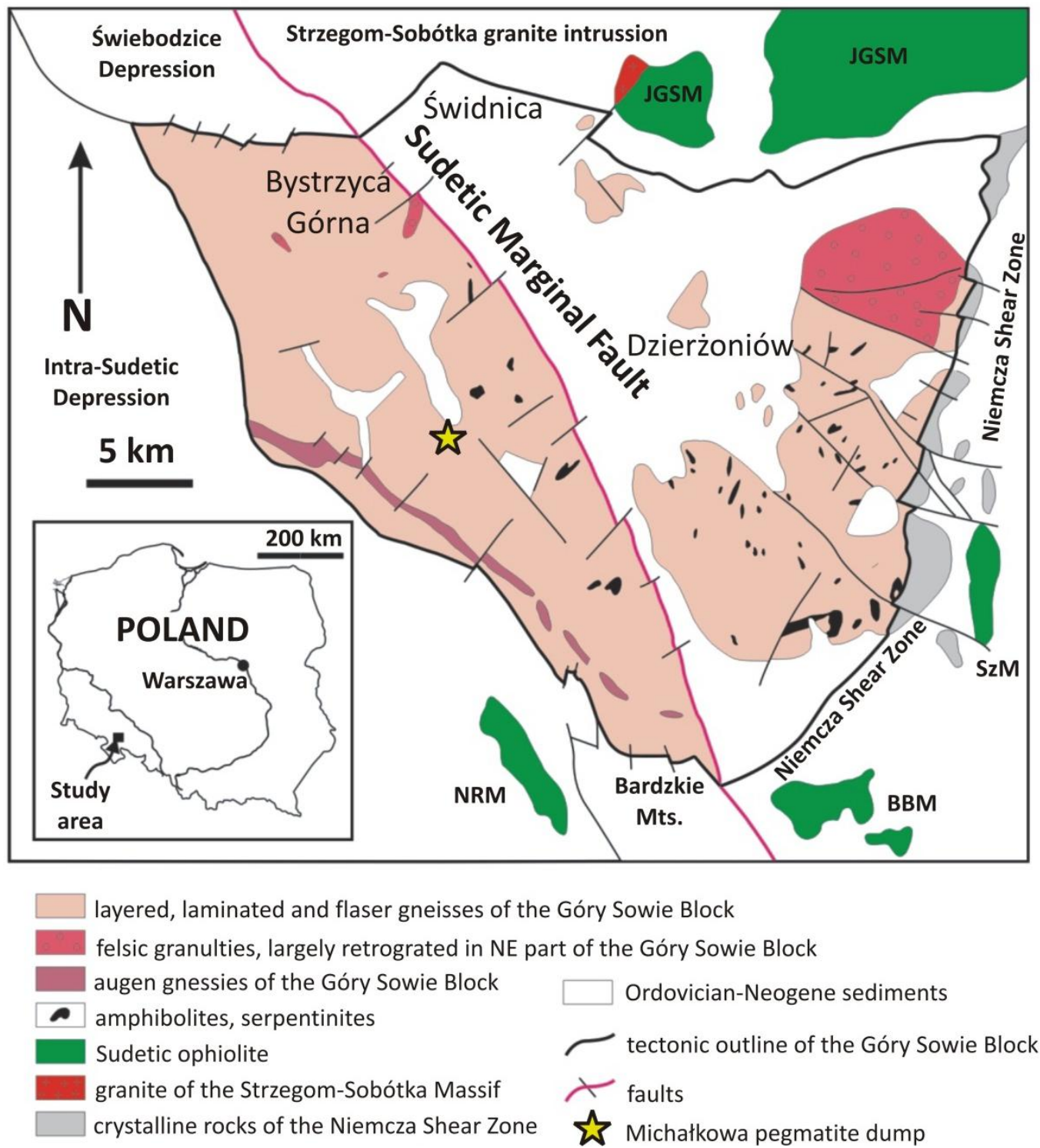

Fig.1. Geological map of the Góry Sowie Block (after Szuszkiewicz et al. 2013, modified).

BBM - Braszowice-Brzeźnica Massif, JGSM - Jordanów-Gogołów Serpentinite Massif;

NRM - Nowa Ruda Massif, SzM - Szklary Massif (all constitute the Sudetic Ophiolite).

\section{Samples and methods}

Two samples of pyrrhotite containing twopyroxene gabbro have been collected from the pegmatite dump in Michałkowa. Mineralogical studies were multistage. All analyses have been performed at the University of Silesia. Mineral abbreviations utilized in this study follow the recommendations of Whitney and Evans (2010) (Tab.1). 
Tab.1. Mineral abbreviations used in this study (after Whitney and Evans (2010)).

\begin{tabular}{ccc}
\hline Mineral name & Formula & Abbrevation \\
\hline Aluminian chromite & $\mathrm{Fe}^{2+}\left(\mathrm{Cr}^{3+}, \mathrm{Al}_{2} \mathrm{O}_{4}\right.$ & $\mathrm{Alc}$ \\
Biotite & $\mathrm{K}\left(\mathrm{Mg}, \mathrm{Fe}^{2+}\right)_{3} \mathrm{AlSi}_{3} \mathrm{O}_{10}(\mathrm{~F}, \mathrm{OH})_{2}$ & $\mathrm{Bt}$ \\
Chalcopyrite & $\mathrm{CuFeS}_{2}$ & $\mathrm{Ccp}$ \\
Chromite & $\mathrm{Fe}^{2+} \mathrm{Cr}^{3+}{ }_{2} \mathrm{O}_{4}$ & $\mathrm{Chr}$ \\
Clinochlore & $\left(\mathrm{Mg}, \mathrm{Fe}^{2+}\right)_{5} \mathrm{Al}\left(\mathrm{AlSi} i_{3} \mathrm{O}_{10}\right)(\mathrm{OH})_{8}$ & $\mathrm{Clc}$ \\
Gersdorffite & $\mathrm{NiAsS}_{2}$ & $\mathrm{Ger}$ \\
Ilmenite & $\mathrm{Fe}^{2+} \mathrm{TiO}_{3}$ & $\mathrm{Ilm}$ \\
Lizardite & $\mathrm{Mg}_{3}\left(\mathrm{Si}_{2} \mathrm{O}_{5}\right)(\mathrm{OH})_{4}$ & $\mathrm{Lz}$ \\
Magnesio-hornblende & $\mathrm{Ca}_{2}\left[\left(\mathrm{Mg}_{5}, \mathrm{Fe}^{2+}\right)_{4} \mathrm{Al}_{3}\left(\mathrm{Si}_{7} \mathrm{Al}\right) \mathrm{O}_{22}(\mathrm{OH})_{2}\right.$ & $\mathrm{Mhb}$ \\
Magnetite & $\mathrm{Fe}^{2+} \mathrm{Fe}^{3+}{ }_{2} \mathrm{O}_{4}$ & $\mathrm{Mag}$ \\
Pentlandite & $\left(\mathrm{Fe}_{2} \mathrm{Ni}_{9} \mathrm{~S}_{8}\right.$ & $\mathrm{Pn}$ \\
Pyrrhotite & $\mathrm{Fe}_{1-\mathrm{x}} \mathrm{S}$ & $\mathrm{Po}$ \\
Talc & $\mathrm{Mg}_{3}\left(\mathrm{Si}_{4} \mathrm{O}_{10}\right)(\mathrm{OH})_{2}$ & $\mathrm{Tlc}$ \\
\hline
\end{tabular}

\subsection{Microscopic methods}

Polished sections were studied by optical microscopy of reflected light and using scanning electron microscopy (SEM) in Laboratory of Scanning Microscopy at Faculty of Earth Sciences, University of Silesia with the use of environmental analytical microscope Philips ESEM XL30/TMP equipped with detector EDS (Energy Dispersive Spectrometer) / EDAX Sapphire type in lowvoltage regime (low vacuum to 1 Torr).

\section{2. $X$-Ray diffraction $(X R D)$}

XRD patterns were obtained with the Philips PW 3710 diffractometer using $\mathrm{CoK} \alpha$ radiation (35 and $45 \mathrm{kV}, \quad 30 \mathrm{~mA}$ ). Powder diffractograms were acquired in the $3-90^{\circ} 2 \theta$ range, with $7-20 \mathrm{~s}$ counting per $0.01^{\circ}$ and $0.04^{\circ}$ $2 \theta$ step. Analyses were performed in the X-Ray Laboratory at Faculty of Earth Sciences, University of Silesia.

\subsection{Mössbauer spectrometry}

Mössbauer spectra were obtained using POLON mössbauer spectrometer with a constant acceleration. The radiation source was a ${ }^{57} \mathrm{Fe}$ in Pd matrix. The velocity scales were calibrated with a $\alpha-\mathrm{Fe}$ foil absorber at room temperature and isomer shifts are quoted with respect to the centroid of these spectra. The spectrometer was operated by MOSIEK software. Mössbauer spectra have been developed in the MOS program. Analyses were performed in the Department of Nuclear Physics and Its Applications at the Institute of Physics, University of Silesia.

\section{Results and discussion}

\subsection{Microscopic observations}

Optical and SEM studies revealed that pyrrhotite crystals up to $2 \mathrm{~cm}$ size are common in two-pyroxene gabro from Michałkowa. They are often associated with pentlandite, chalcopyrite (Fig. 2, 3), ilmenite (Fig. 3c), gersdorffite (Fig. 3d) and chromite ones (Fig. 3b). These last form crystals up to $15 \mu \mathrm{m}$ size with oscillatory concentric zoning caused by variations in the proportions of their major elements (Fe, Mg, Al, Cr) (Fig. 3b). 


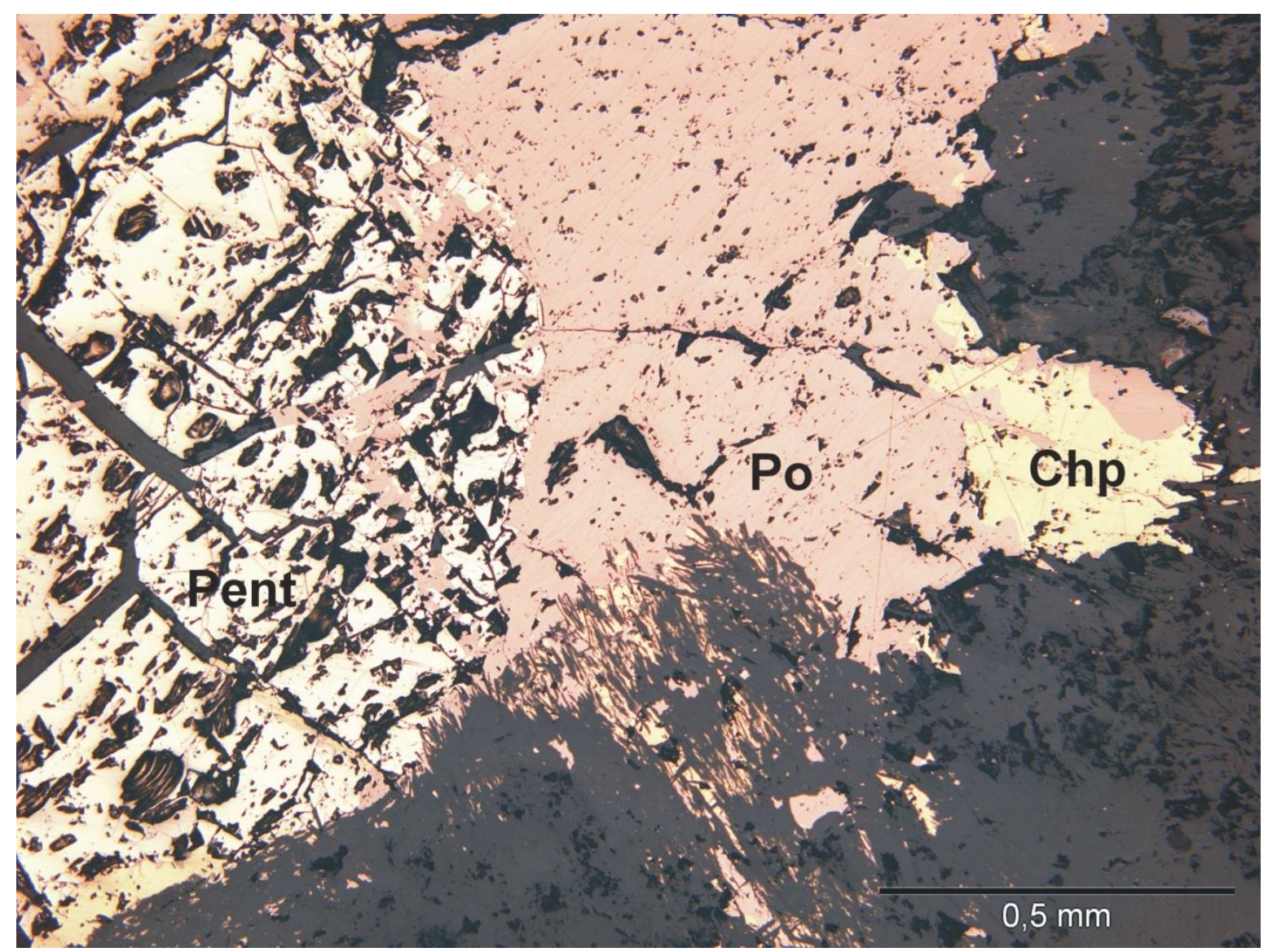

Fig.2. Microphotograph in reflected light of pyrrhotite associated with pentlandite and chalcopyrite (IN).
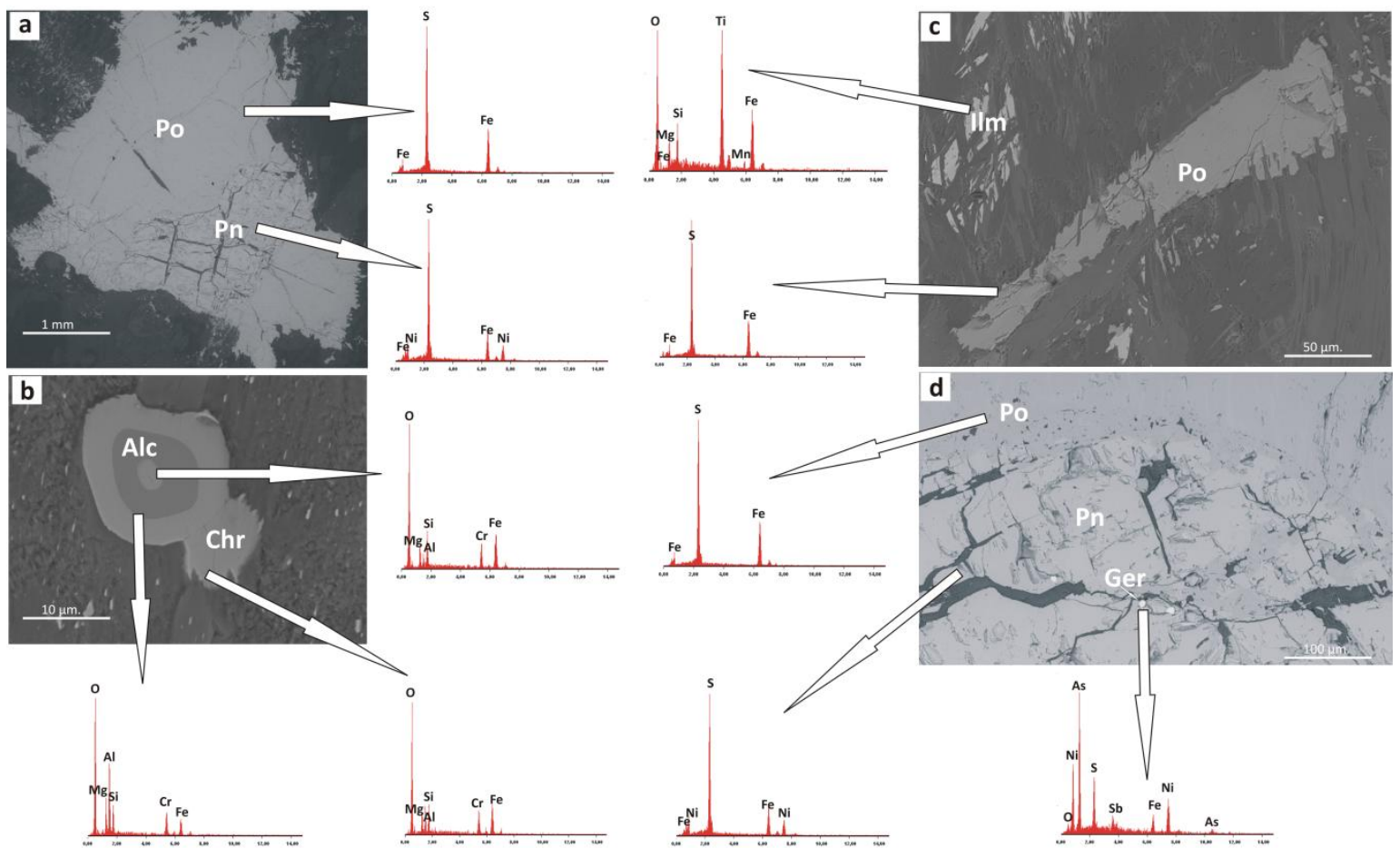

Fig.3. SEM images (BSE) and EDS spectra of studied samples. A) Pyrrhotite with pentlandite; B) Zonal structured mineral (oscillatory concentric zoning) of the spinel group with ferrous-chromium zones inside and outside (chromite) and aluminian-ferrous-chromium between them (aluminian chromite); C) Pyrrhotite with ilmenite; D) Pyrrhotite with pentlandite and gersdorffite. 


\subsection{X-Ray powder diffraction}

Pyrrhotite unit cell dimensions vary with changes in the chemical composition (Ramsdell 1927; Grönvold and Haraldsen 1952). Arnold and Reichen (1962) have shown that the relation of interplanar distance $d_{102}$ and iron content in pyrrhotites can be useful in estimating the chemical composition of pyrrhotites and calculating the $\mathrm{x}$ parameter. The most Fe-deficit phases have the smallest $\mathrm{d}_{102}$ values, while the increase of the iron content results in greater interplanar distance $\mathrm{d}_{102}$ which changes in the following ranges: from $\mathrm{d}_{102}=2.0591 \AA$ in monoclinic $4 \mathrm{C}$ pyrrhotite from Chichibu Mine, Akaiwa, Japan with a composition of $\mathrm{Fe}_{7} \mathrm{~S}_{8}$ (Morimoto et al. 1975) to $\mathrm{d}_{102}=2.0952 \AA$ in troilite from Long Island meteorite, Kansas, USA (Carpenter and Desborough 1964).
XRD analysis indicate that studied pyrrhotite has orthorhombic $11 \mathrm{C}$ structure with $\mathrm{a}=3.433(9) \AA, \mathrm{b}=5.99(2) \AA, \mathrm{c}=5.7432(5) \AA$, $\beta=90^{\circ}$, very similar to that described by Morimoto et al. (1970). The $d_{102}$ value was obtained to be $2.06906 \AA$ indicating the composition near $\mathrm{Fe}_{10} \mathrm{~S}_{11}$ and $\mathrm{x}=0.0909$.

In addition to the phases identified by microscopic methods, pyrrhotite occurs with magnetite, biotite and magnesio-hornblende. These last two phases indicating the hydratation of igneous interstitial alloys or subsolidus processes - amphibolization or biotitization (Fig. 4). Moreover, the presence of clinochlore, lizardite and talc indicates that chloritization and serpentinization processes have had some impact on the studied samples (Fig. 4).

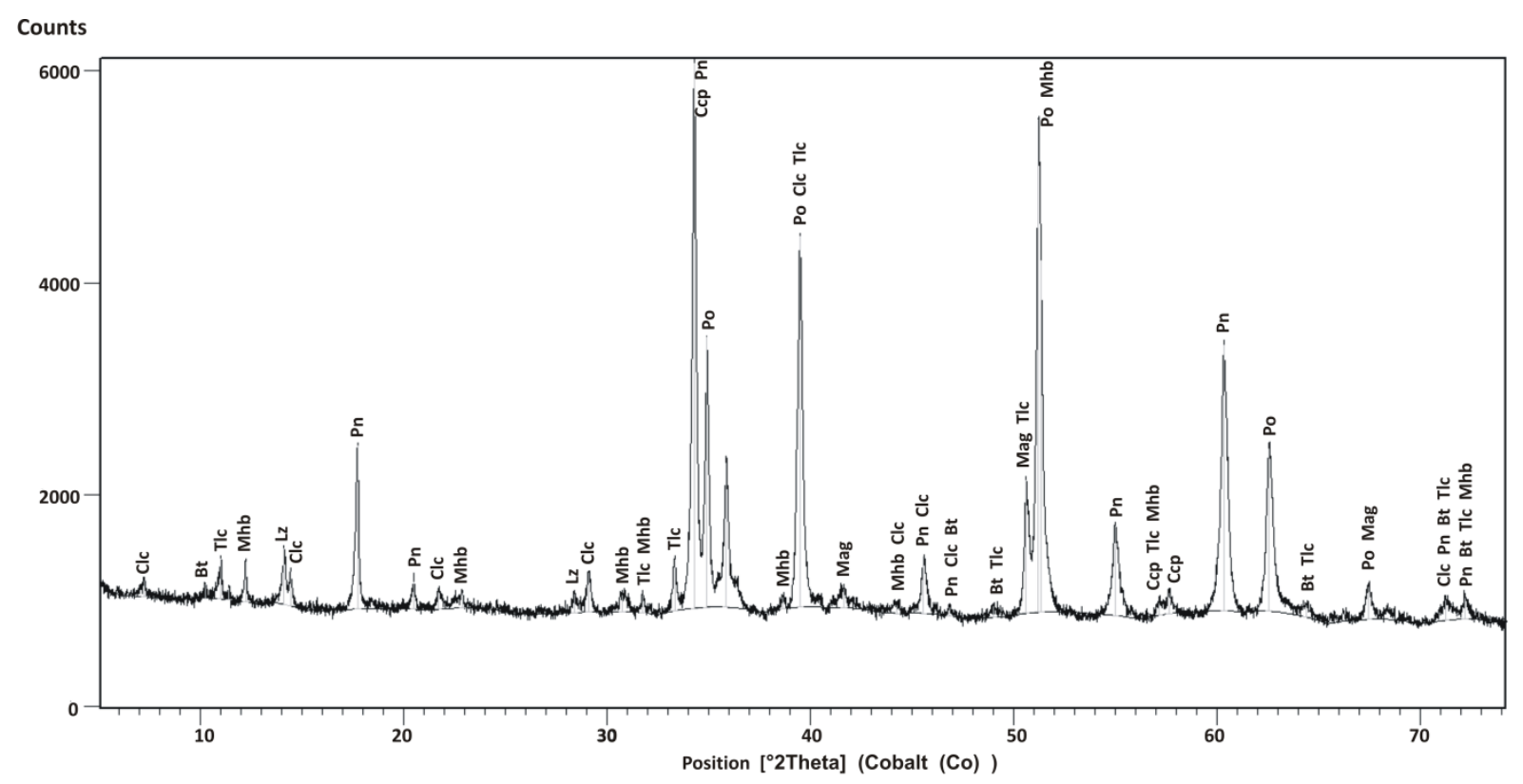

Fig.4. Diffractogram of the studied sample. Mineral abbreviations such as in Table 1.

\subsection{Mössbauer data}

Three pyrrhotite sextets (A, B, C) are typical for low iron content pyrrhotites (with high values of $\mathrm{x}$ ). For small values of $\mathrm{x}$, only one sextet (indicating one type of $\mathrm{Fe}$ position) is reported up to $\mathrm{x}=0.042$, the interval $0.054<\mathrm{x}$
$<0.079$ is characterized by broad peaks, while in phases with values $0.106<\mathrm{x}<0.143$ three well-resolved sextets are observed (Kruse 1990).

Analysis of the hyperfine splitting parameter $(\mathrm{H})$, which is proportional to the total local magnetic field in the core 
surrounded by the magnetic field, gave the information about the magnetic arrangement and structure of the studied pyrrhotite. The higher $\mathrm{H}$ values are observed for the more disordered structures, which means a higher symmetry (Kruse 1990; Rybicki 2011).

In Michałkowa pyrrhotite three sextets with hyperfine parameter values $30.8 \mathrm{~T}$ for sextet A, 27.9 T and 25.8 T for sextets B and C respectively, were observed (Fig. 5, Tab. 2). These values are higher in comparison to the 4C monoclinic pyrrhotites from the Polish Sudetes and lower than in the troilite from
Morasko meteorite (see Rybicki 2011), indicating that pyrrhotite from Michałkowa two-pyroxene gabbro is most likely orthorhombic.

Besides the pyrrhotite's sextets, two doublets have been identified based on data from McCammon (1995). The doublet D with isomer shift (IS) $=0.38 \mathrm{~mm} / \mathrm{s}$ and quadrupole splitting $(\mathrm{QS})=0.14 \mathrm{~mm} / \mathrm{s}$ fits the spectrum of pentlandite (Fig. 5, Tab. 2), while doublet E with IS $=1.12 \mathrm{~mm} / \mathrm{s}$ and $\mathrm{QS}=1.29 \mathrm{~mm} / \mathrm{s}$ is most likely derived from magnesio-hornblende (Fig. 5a, b, Tab. 2).

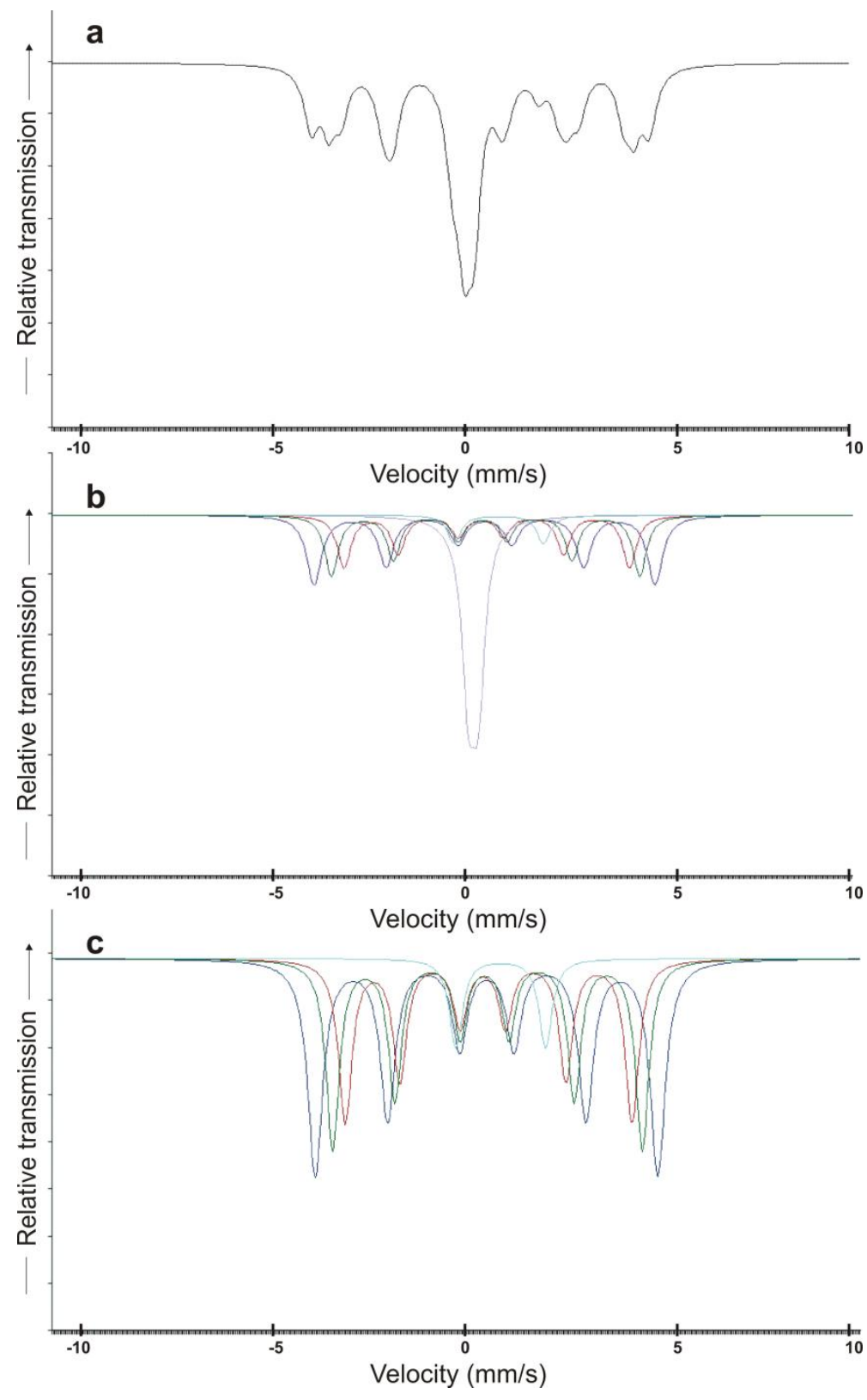

Fig.5. Mössbauer spectra of the studied sample. The subspectra colors are the same as in Table 2. A) Mössbauer total spectrum; B) Mössbauer spectrum divided into subspectra; C) Mössbauer spectrum divided into subspectra without magnesio-hornblende subspectrum 
Tab.2. Mössbauer data for studied sample.

\begin{tabular}{lcccc}
\hline \multicolumn{1}{c}{ Mineral } & Subspectrum & IS $(\mathbf{m m} / \mathbf{s})$ & QS $(\mathbf{m m} / \mathbf{s})$ & H $(\mathbf{T})$ \\
\hline \multirow{3}{*}{ Pyrrhotite } & A & 0.71 & 0.01 & 30.8 \\
& B & 0.70 & -0.04 & 27.9 \\
\hline Pentlandite & C & 0.69 & -0.08 & 25.8 \\
\hline Magnesio-hornblende & D & 0.38 & 0.14 & - \\
\hline
\end{tabular}

\section{Conclusions}

This study provides the first description of orthorhombic pyrrhotite from Polish Sudetes. It occurs in two-pyroxene gabbro with pentlandite, chalcopyrite, chromite, aluminium chromite, ilmenite, gersdorffite, magnetite, biotite, magnesio-hornblende, clinochlore, lizardite and talc.

Pyrrhotite has orthorhombic $11 \mathrm{C}$ structure with $\mathrm{a}=3.433(9) \AA, \mathrm{b}=5.99(2) \AA, \mathrm{c}=$ 5.7432(5) $\AA, \beta=90^{\circ}$ and $\mathrm{d}_{102}=2.06906 \AA$.

Mössbauer studies confirm XRD data. Pyrrhotite has three sextets with hyperfine parameter values $30.8 \mathrm{~T}$ for sextet A, $27.9 \mathrm{~T}$ and $25.8 \mathrm{~T}$ for sextets $\mathrm{B}$ and $\mathrm{C}$ respectively, indicating orthorhombic structure, the composition near $\mathrm{Fe}_{10} \mathrm{~S}_{11}$ and the value of $\mathrm{x}$ parameter $=0.0909$.

\section{Acknowledgements}

Authors would like to thank Dr. Eligiusz Szełęg for his help in sampling.

\section{References}

Arnold R.G., Reichen L.E. (1962) Measurement of the metal content of naturally occurring, metal-deficient hexagonal pyrrhotite by an X-ray spacing method. American Mineralogist, 47, 105111.

Becker M., Bradshaw D., De Villiers J.P.R. (2011) The mineralogy of pyrrhotite from Sudbury CCN and Phoenix nickel ores and its effect on flotation performance. Can. Metall. Q., 50 (1), 10-19.

Carpenter R.H., Desborough G.A. (1964) Range in solid solution and structure of occurring troilite and pyrrhotite. American Mineralogist, 49, 1350-1365.

De Villiers, J.P.R., Liles, D.C., Becker, M. (2009) The crystal structure of a naturally occurring 5C pyrrhotite from Sudbury, its chemistry, and vacancy distribution. American Mineralogist 94, 1405-1410.

De Villiers J.P.R., Liles D.C. (2010) The crystal-structure and vacancy distribution in $6 \mathrm{C}$ pyrrhotite. American Mineralogist, 95, 148-152.

Evans H.T. (1970) Lunar troilite: Crystallography. Science, 167, 621-623.

Fleet M.E. (2006) Phase equlibria at high temperatures. In: DJ Vaughan (ed.) Sulfide Mineralogy and Geochemistry. 365-419. (MSA: Washington DC, USA).

Grønvold F., Haraldsen H. (1952) On the phase relations of synthetic and natural pyrrhotites (Fe1-xS). Acta Chemica Scandinavica, 5, 1452-1469.

Kontny A., de Wall H., Sharp G.P., Pósfai M. (2000) Mineralogy and magnetic behavior of pyrrhotite from a $260^{\circ} \mathrm{C}$ section at the KTB drilling site, Germany. American Mineralogist, 85, 1416-1427.

Koto K., Morimoto N., Gyobu A. (1975) The superstructure of intermediate pyrrhotite. I. Partially disordered distribution of metal vaccancy in the $6 \mathrm{C}$ type, $\mathrm{Fe}_{11} \mathrm{~S}_{12}$. Acta Crystallographica, B31, 2759-2764.

Kruse O. (1990) Mössbauer and X-ray study of the effects of vacancy concentration in 
synthetic hexagonal pyrrhotites. American Mineralogist, 75, 755-763.

Lilies D.C., De Villiers J.P.R. (2012) Redetermination of the structure of $5 \mathrm{C}$ pyrrhotite at low temperature and at room temperature, American Mineralogist, 97, 257-261.

Łodziński M., Sitarz M. (2009) Chemical and spectroscopic characterization of some phosphate accessory minerals from pegmatites of the Sowie Góry Mts, SW Poland, Journal of Molecular Structure 924-926, 442-447.

McCammon, C. (1995) Mössbauer Spectroscopy of Minerals. In: TJ Ahrens (ed.) Mineral Physics and Crystallography, A Handbook of Physical Constants, The American Geophysical Union, 332-347.

Morimoto N., Nakazawa H., Nishiguchi K., Tokonami M. (1970) Pyrrhotites: Stoichiometric compounds with composition $\mathrm{Fe}_{\mathrm{n}-1} \mathrm{~S}_{\mathrm{n}}(\mathrm{n} \geq 8)$. Science, 168, 964-966.

Morimoto N., Gyobu A., Mukaiyama H., Izawa E. (1975) Crystallography and stability of pyrrhotites. Economic Geology, 70, 824-833.

Pósfai M., Sharp T.G., Kontny A. (2000) Pyrrhotite varieties from the $9.1 \mathrm{~km}$ deep borehole of the KTB project. American Mineralogist, 85, 1406-1415.

Powell A.V., Vaqueiro P., Knight K.S., Chapon L.C., Sanchez R.D. (2004)
Structure and magnetism in synthetic pyrrhotite $\mathrm{Fe}_{7} \mathrm{~S}_{8}$ : A powder neutrondiffraction study. Physical Review, B70, 014415-1-014415-12.

Ramsdell L.S. (1927) X-ray data on some sulfide minerals (abstr.). American Mineralogist, 12, 79.

Rybicki M. (2011) Badania mössbauerowskie siarczków żelaza grupy pirotynu $\mathrm{z}$ wybranych lokalizacji Sudetów oraz meteorytów. Interdyscyplinarne zagadnienia $\mathrm{w}$ górnictwie $\mathrm{i}$ geologii, 2, 129-137 (in Polish).

Szuszkiewicz A., Szełęg E., Pieczka A., Ilnicki S., Nejbert K., Turniak K., Banach M., Łodziński M., Różniak R., Michałowski P. (2013) The Julianna pegmatite vein system at the Piława Górna Mine, Góry Sowie Block, SW Poland - preliminary data on geology and descriptive mineralogy, Geological Quarterly, 57, 467-484.

Yamamoto, A. and Nakazawa, H. (1982) Modulated structure of the NC-type $(\mathrm{N}=$ 5.5) pyrrhotite, $\mathrm{Fe}_{1-\mathrm{x}} \mathrm{S}$. Acta Crystallographica, A38, 79-86.

Websky (1868) Zeitschrift der Deutsche geologische Gesellschaft, Berlin: 20: 245 (in German).

Whitney D.L, Evans B.W. (2010) Abbreviations for names of rock-forming minerals, American Mineralogist, 95, 185187. 